\title{
THE GENESIS OF REAL ESTATE OWNERSHIP IN UZBEKISTAN, ITS CURRENT STATUS, AND IMPROVEMENT PERSPECTIVES
}

\author{
Muattar Allayorova \\ Independent researcher at Tashkent state university of law, \\ Republic of Uzbekistan \\ sayqalbek26@gmail.com
}

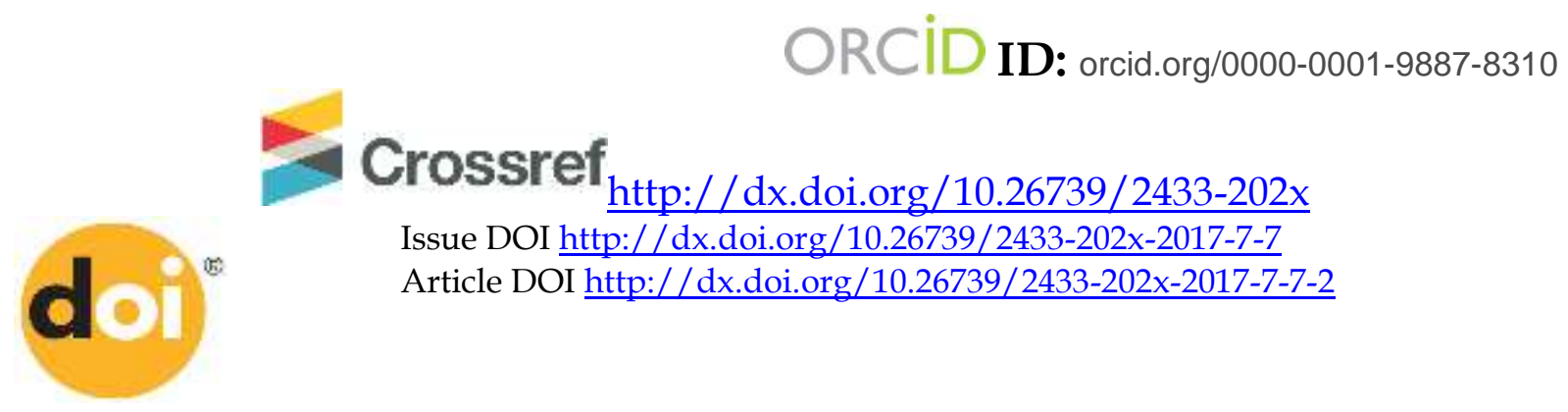

Abstract: In paper author try to explore denationalization and privatization. During the years of independence, property issues have gained a new meaning, creating a wide range of possibilities and legal grounds for housing as a type of real estate. The existence of legal requirements for the registration of housing rights and freedom of transformation of the rights from one individual to another serves to ensure the rights and legitimate interests of civilians.

Keywords: real estate ownership, genesis and status ownership, Republic of Uzbekistan, law system.

Ownership right for the housing, unlike other types of property, was of particular importance throughout human history. Housing matters have always been among the most critical ones and have been given special attention by the state, society, and individuals. Having gained its independence, the Republic of Uzbekistan initiated massive economic, social, cultural and other reforms. Market economy prevailed, and absence of property limits as well as the diversity of owner types has been guaranteed by the law.

If we cast a look back, Muslim law dominated in Uzbekistan right up to the foundation of the Soviet Union. All matters associated with housing Social science and humanities

M.Allayorova 
arguments and conflicts were settled out by Qozi (judges). In Muslim law, all buying and selling negotiations had to follow particular rules. First of all, separate regulations were initiated for items which could be treated and could not be included into the buying and selling relationships. In this regard, categories like "halal" and "haram" were of great importance. These ideas were applicable not only to the way of life but also to a wide range of items. The house sales contracts scoped also covered permanent (immovable) household items. If a person was selling his house with a lock on the door, the key from the lock was also regarded to be within the contract scope, since in this case, the key was an inseparable part of the house. Naturally, the key was mentioned in the sales contract without exception, as without a key the lock was completely useless ${ }^{1}$.

In Soviet Union period, the special legal regime was introduced for real estate operations. Henceforth, citizens could legally own housing as their private property. Land, being socialistic state property, could be possessed by individuals only based on the right of use. At the end of 1918 municipal housing stock was founded and placed under control of local councils. From 1917 for many years ahead the legal system of former Union refused to admit real estate transactions as an independent component of civil legal relations ${ }^{2}$. As a result, the status of civil law as a separate branch and its importance had been frequently undermined. Furthermore, In Soviet Union times sale and resale of real estate was accepted with suspicion and was not considered as an indicator of the real financial need of the seller ${ }^{3}$. For this reason Article 257 of Civil Code of Soviet Union specified that if a house (or its part) was owned by a citizen, his/her spouse or their non-adult children, the real estate or it's part was allowed to be an item of purchase and sale contract and put an obligation on the owner not sell the house or its part within a three-year period. If a citizen wanted to sell the house more than once within a threeyear period, each particular case used to be thoroughly reviewed by regional and municipal public deputy executive committees, and the transaction could take place only when there was a valid reason.

If more than one houses were owned by a citizen, his/her spouse or their non-adult children in a lawful way, the owner having reserved the right to keep at will any one of the houses, had to sell, give as a gift or by any other means transfer the ownership of one of the houses to another individual. If

\footnotetext{
${ }^{1}$ Al-heedoya. Muslim law commentaries. /Edited by A.Kh.Saidova. V.1-2. - Moscow.: Volters Kluver, 2008. p. 565

2 Decree by the Council of Public Commissars dated $14^{\text {th }}$ December 1917 "On the prohibition of real estate transactions". With this document passed all real estate trade, collateral and other transactions were suspended.

${ }^{3}$ O. S. Ioffe Selected works. V.3. Contractual Law. - Saint-Petersburg: Press” legal center, 2004, p. 264 (p. 837 ).
} 
the owner failed to discard the extra property within legally established time, regional, municipal and the municipality district Soviet executive committee would sue him to sell the house in a compulsory manner with corresponding court fees deducted and remaining amount returned to the owner. In case the abovementioned property remained unsold, according to regional or municipal Soviet executive committee's decree it could be converted into state property and added to public deputy local council housing stock. Any citizen could own only one house. In Soviet Union times, real estate sales contract was formalized in two different ways depending on the location of the housing. According to Article 258 of Civil Code of Uzbek SSR adopted in 1963, sales contract for housing located in cities or urban-type communities, if at least one of the parties was a resident, should have been notarized and listed in regional, municipal and municipality district Soviet executive committee's register. In rural communities, sales contract should have been prepared in written form and listed in community Soviet executive committees register. In abovementioned cases, in rural areas (in contrast to cities) notarization of sales contracts was not required. The Soviet legal system also had another peculiarity as the institution of real estate sales contract was limited by law, specifying that a citizen could have a house or its part in private ownership with its total area not exceeding 60sq.m. In the same manner, if a house was kept unattended or if poor maintenance by the owner could result in its significant damage, the local Soviet executive committee could specify a period of time for the house to be repaired. In case the house was not repaired by the scheduled time, it was converted to local municipality asset free. Distribution of state-owned housing was a distinct way to make people dependent on the country. The limitations resulted from existing social and economic system and supremacy of state property law in this regard was kept inviolable.

After the Republic of Uzbekistan gained its independence, massive reforms in all spheres of social life were initiated. Equality of all forms of property and their equal protection by the law (real estate in particular), legal guarantees for the freedom of real estate transaction and inviolability of private property rights was guaranteed by the law.

Due to the good fertility of the lands in the Republic of Uzbekistan, Soviet government made cotton growing the absolute agricultural priority. In large families, parents were obliged to reside in one farmstead with three to four their married children. With spouses, the number of total each household reached 20 or even 30 persons per house. 
To put an end to the situation described above, having met in enlarged session in Tashkent on 17th August, 1989, republican government leaded by Islam Karimov discussed the issue of allocating household and personal plots to population and adopted a resolution "On providing rural families with household plots and creating all conditions for private housing construction". According to this historical document, every person in rural areas was supposed to receive the average of 2,500 sq.m. of land and have his household plot enlarged by 4.5 times. As a result of this measure practically implemented, in 1989 1990 over 1.5 million families were allocated in additional land and 700.000 families were granted new household plots ${ }^{4}$.

A law "On property" adopted on 31 ${ }^{\text {st }}$ October 1990 while property relations were still being state-regulated is worth paying separate attention ${ }^{5}$ since it can be considered a fundamental law to define various forms of property, particularly, private property in our country.

Denationalization and privatization were considered among the most critical factors behind moving toward a market economy. State law "On denationalization and privatization" adopted on 19th November 1991 set up a legal basis to denationalization and privatization. Privatization of housing stock in the Republic of Uzbekistan was given special priority, whereas the concept was largely developed in the law "On state housing stock privatization" adopted on 07th May 1993. According to Article 1 of the abovementioned law, privatization of state property essentially meant that citizens on their own accord could buy (also at subsidized price) or receive for free the housing they used to reside in and which used to be a part of state existing housing stock or newly constructed apartments or houses or their part. Based on the abovementioned law, almost entire state-owned housing stock has been privatized and turned into corresponding citizens' private property. A set of decrees associated with privatization has been issued by the first President of the Republic of Uzbekistan. According to the resolution "On additional privileges granted to disabled war veterans, veterans, internationalist servicemen on the occasion of $45^{\text {th }}$ anniversary of victory of Soviet people in Great Patriotic War" adopted on $8^{\text {th }}$ of May 1990, Great Patriotic War veterans' apartments and houses, which had previously been owned by state or public companies, were converted into their private property. This resolution played an important role in advancing the privatization progress. Its importance and uniqueness lay in the fact that

\footnotetext{
${ }^{4}$ I. Karimov "Uzbekistan on its way to independence" - Tashkent. "Uzbekistan" 2011. p.12.

${ }^{5}$ Uzbekistan SSR Supreme Soviet report 1990. No. 31 33, Paragraph 371.
}

Social science and humanities

M.Allayorova 
Uzbekistan was the first of the Union republics (the Union at that time still existed) to introduce the concept of free transfer of real estate from state housing stock to private ownership and to create the basic principles for free privatization. It is worth highlighting that the concept was later implemented by a number of CIS countries (for example, Russian Federation) ${ }^{6}$. Subsequently, similar benefits granted to teachers of various schools, kindergarten teachers, professors and teaching staff in higher and secondary specialized educational institutions of the Republic, researchers and other employees of educational institutions, creative and medical staff, or, in other words, to the most vulnerable segments of the population formed the basis for the adoption of a number of relevant presidential decrees. Another feature of privatization was that non-adult children residing in a house were also considered participants in the privatization process and had equal rights with other owners.

As a result, the above-mentioned events contributed to the improvement of the legislative framework. In particular, the Resolution of the President No. PP-10 "On further development of housing construction and the housing market" dated $16^{\text {th }}$ February 2005, the law "On mortgage" dated $5^{\text {th }}$ October 2006, the President's resolution "On measures on organization of Mortgage Lending Support Fund" No. PP-69 dated 6 $6^{\text {th }}$ May 2005, approved by the Decree of the Cabinet of Ministers No. 2 dated 3rd January 2007 "On approval of the mortgage loans for housing construction, reconstruction and purchase" were adopted introducing relevant amendments into the legislative framework of the Republic of Uzbekistan.

A rapid growth of the market economy and widespread property relations caused a need for the real estate legislation at the level of a single uniform set of codified laws. As a result, the Housing Code of the Republic of Uzbekistan was adopted on $1^{\text {st }}$ April 19997. Current housing legislation specifies that housing rights have to be approved by a notary and entered in the Unified State Register. In addition to the Civil Code, these kinds of issues are regulated by No.1 Decree of the Cabinet of Ministers dated 7th January 2014 "On improving the procedure of state registration of rights to immovable property".

In Soviet times, the allocation of land was not legally ordered. In a corresponding way, the land allocated for housing construction was registered in rural registry books for the name of the head of a family, which

\footnotetext{
${ }^{6}$ F.F.Mukhitdinova Property right of citizens to housing and its judicial protection under the laws of the Republic of Uzbekistan. - Tashkent: Academy of Science, Institute of Philosophy and Law named after I.M. Muminov. p. 13

${ }^{7}$ Republic of Uzbekistan Supreme Council report. 1999. No. 1. Paragraph 4.
}

Social science and humanities

M.Allayorova 
has become a cause of numerous property disputes in courts. Today, private ownership of land is not prohibited, but it is not widespread. Land for housing received by citizens in conformity with the property rights, precisely according to Article 165 of the Civil Code the ownership is given on the basis of the right of lifelong inheritable possession of the land parcel.

According to the decree of the first President of the Republic of Uzbekistan dated 24 July 2006 N UP-3780 "On the privatization of land occupied by buildings and structures of legal entities and citizens" starting from $1^{\text {st }}$ January 2007, legal entities - residents, owning buildings and facilities or having them privatized are also entitled to privatize the lands with industrial infrastructure located on it, as well as the adjacent territories, if they are used to carry out relevant technological processes, with regard to urban planning regulations and in the amount necessary to carry out production process. Also, starting from $1^{\text {st }}$ January 2008, residents of Uzbekistan were given the right in accordance with the established procedure to privatize land plots allocated for housing or residential housing maintenance purpose. As a result, turnover of privatized land has become possible, in particular by easing restrictions on the transaction on their sale and purchase, exchange, gift, inheritance, use (leasing) and use as collateral for loans received in a bank or another credit institution.

To have the above-mentioned decree fully implemented in practice, in particular to make the land be an object of civil rights, and for the decree's full formation a mechanism had to be introduced. In this way, annuity contract played its important role to make the land be an object of civil law. Section 32 of the Civil Code of the Republic of Uzbekistan, containing rules related to rent contracts, determines that the recipient of rent passes his immovable or movable property into the ownership of the rent payer, and receives periodic payments in cash or in another form. It also implies making payments for the use of land by rent payer to the recipient of rent. This approach is considered as widely distributed and specific basis for the implementation of property rights with respect to the housing. However, due to not fully formed proprietor class in our society, rent contract and ground rent contracts, in particular, do not function properly. Nevertheless, first Presidents and President Sh. Mirziyoyev's special attention to the development of small enterprises and private entrepreneurship resulted in numerous reforms and continuous expansion of proprietor class. As a result, there is a need for property rights to be replaced by private property.

Numerous reforms in various fields and industries are being currently 
implemented in our country. Among the government initiatives aimed at improving living conditions and creating additional facilities, the construction of model houses in our country is worth special attention.

16-17th April 2013 the first President of Uzbekistan Islam Karimov in his speech at the opening ceremony of the conference on "Modern housing construction as a driving force of comprehensive development and transformation of rural areas, enhancing the living standards of population" outlined the priority tasks of the state policy aimed at providing housing for citizens. Nowadays, houses built in the cities and countryside are equipped with all necessary utilities and citizens having paid $25 \%$ of the value of the house from their own funds, receive a loan on favorable terms at a preferential interest rate for up to 15 years with no interest paid in the first year and $7 \%$ annual interest fixed for the subsequent period.

O. Okyulov states that in the past, application for financial assistance in the absence of collateral was considered as a drastic measure. However, in market conditions, collateral, especially real estate collateral is perceived by the most active, agile, skillful part of the population experiencing temporary financial need as an effective way to obtain required funds and later return them without unnecessary complications ${ }^{8}$. Continuing this idea, the historical experience of most countries indicate that the development of housing and infrastructure, is a priority area, became a means of restoring the national economy. For example, during the crisis of the 1930s, called the Great Depression, President Roosevelt introduced the individual housing construction lending scheme, and this reform managed to become an important factor for further economic growth. In due time similar programs aimed at restoring or stimulating the economy were adopted in Germany, UK, Scandinavia and other countries ${ }^{9}$. People's demand for housing is becoming a subject of public relations and being raised to the level of state policy, and step by step is being fulfilled as planned.

In order to carry out the works associated with individual housing construction, an entire institutional structure has been established in rural areas. Model home design, as well as the necessary social as well as engineering and communication infrastructure related designed residential areas were entrusted to "Qishloq Qurilish Loyiha" design and research

\footnotetext{
${ }^{8}$ O.Oqyulov. The international recognition of the Uzbek model of modern residential construction. The Right and Duty, 2013. No.8.

${ }^{9}$ Islam Karimov. Speech at the opening ceremony of the international conference on "Modern housing construction as a driving force of comprehensive development and transformation of rural areas, enhancing the living standards of population" Word of Nation newspaper. 17 $7^{\text {th }}$ April 2013, No. 73.
}

Social science and humanities

M.Allayorova 
institute. At the same time, the Institute carries out supervision during construction. Joint-stock commercial "Qishloq Qurilish Bank" was established to finance the project on credit basis. It is also supported by the National Bank for Foreign Economic Activity and Ipoteka Bank. Execution of all construction works with a commitment to deliver the model houses ready to be moved into was assigned to "Qishloq Qurilish Invest" special engineering company. Being the only contractor, the company has opened branch offices in all regions of our country and consistently carries out a policy of monitoring the quality of constructed residential housing. According to the approved regulations in rural areas, the construction of houses is carried out individually by building organizations based on approved design, and houses themselves are built together with relevant engineering services, social and market infrastructure. Construction of roads and internal communications as well as connection to water, gas, and electricity service lines are financed from the state and local budgets. The corresponding number of schools, kindergartens, rural medical centers, shopping centers and sports facilities are constructed with reference to the size of the population in the residential area. We can emphasize with pleasure that these state policies are actively supported by the Asian Development Bank, Islamic Development Bank, the World Bank and other international financial organizations.

According to Roland Laurey (one of the international experts, architect, and director of the company "Laurey Architecture \& Environment", Germany), special attention shall be given to the use of achievements of national and modern architecture in the construction of residential areas. He also emphasized that comfortable living conditions were created for homeowners, so that they could enjoy the same level of comfort as urban population does. According to Dr. Kamol Kitsawada (PR at Assumption University of Thailand) housing construction in rural areas, the reliability of established system, aimed at improving the welfare of the population in Uzbekistan, the way it is different from similar schemes implemented in other countries, payment of $25 \%$ of the house value and financing the remainder by the special banks with commitment to repay the debt for 15 years on favorable terms, as well as handing the house over to the customer ready for operation is an excellent example to study and emulate. Moreover, Lucio Askuini (director of "Archest" architecture and engineering company, Italy) stressed the importance of creating a complete social infrastructure, which would include a qualitative improvement of medical and educational 
institutions, public service facilities, cultural and public networks along with the appearance of rural areas and the rise in living standards.

The state policy pursued by the First President of the Republic of Uzbekistan I.Karimov is being continued by the President of the Republic of Uzbekistan Sh.Mirziyoyev. This can be seen in the adoption of the Resolution of the President of Uzbekistan "About the Program of Constructing Cheap Housing on Renewable Standardized Projects within the Countryside in 2017-2021" 21 st October 2016. The resolution establishes a number of measures to radically increase the life of the population in the countryside with modern and comfortable housing. In addition, with this resolution, new models of cheap houses were introduced to the existing standard designs. According to new design along with the buildings in the densely populated areas, one-storey 2 and 3 roomed houses are located on land parcels of 0.02 hectares and united storey 4 bedroom houses are placed on land plots of 0.04 hectares.

In addition, home constructors receive mortgages with 3 years of grace period and 7 percent interest rate per annum in the first 5 years and in the next refinancing rate of the Central Bank for a period of 15 years. Whereby the initial fee of the home constructors is as follows: it is planned to provide 25 percent of preferential loans for two-storey 4-roomed houses and 15 percent for 2 and 3-storied apartment buildings and one-storied 2 and 3bedroom houses.

In conclusion, we can highlight the appearance of the primary and secondary housing market in Uzbekistan. Infrastructure has been established, realtor services have become more and more widespread. A law "On the pledge registry" has been adopted. The real estate prices tend to decrease gradually.

At the same time, each historical development stage is specifically regulated by the subject matter of the purchase and sale contract, the right of ownership to it and the transfer from one person to another. During the Soviet Union times, real estate ownership was forbidden, including free dealing of the housing. This was a period when private ownership was viewed as a sign of "wealth" and "capitalism", and this led to the prohibition of ownership by the law, destruction of the class of proprietors, domination of the single state property. During the years of independence, property issues have gained a new meaning, creating a wide range of possibilities and legal grounds for housing as a type of real estate. The existence of legal requirements for the registration of housing rights and freedom of 
transformation of the rights from one individual to another serves to ensure the rights and legitimate interests of civilians. 


\section{References}

1. Al-heedoya. Muslim law commentaries. /Edited by A.Kh.Saidova. V.1-2. - Moscow.: Volters Kluver, 2008. p. 565

2. Decree by the Council of Public Commissars dated $14^{\text {th }}$ December 1917 "On the prohibition of real estate transactions". With this document passed all real estate trade, collateral and other transactions were suspended.

3. F.F.Mukhitdinova Property right of citizens to housing and its judicial protection under the laws of the Republic of Uzbekistan. - Tashkent: Academy of Science, Institute of Philosophy and Law named after I.M. Muminov. p.p. 11-13

4. Islam Karimov. Speech at the opening ceremony of the international conference on "Modern housing construction as a driving force of comprehensive development and transformation of rural areas, enhancing the living standards of population" Word of Nation newspaper. 17th April 2013, No. 73.

5. I. Karimov "Uzbekistan on its way to independence" - Tashkent. “Uzbekistan" 2011. p.12.

6. O.Oqyulov. The international recognition of the Uzbek model of modern residential construction. The Right and Duty, 2013. No.8.

7. O. S. Ioffe Selected works. V.3. Contractual Law. - SaintPetersburg: Press" legal center, 2004, p. 264 (p. 837).

8. Republic of Uzbekistan Supreme Council report. 1999. No. 1. Paragraph 4.

9. Uzbekistan SSR Supreme Soviet report 1990. No. 31 33, Paragraph 371. 